\title{
PENERAPAN SANKSI PIDANA MINIMUM KHUSUS PADA TINDAK PIDANA NARKOTIKA (Studi Putusan Nomor 111/Pid.Sus/2017/PN Sag)
}

\section{Denny Latumaerissa}

\author{
dino elbarca@yahoo.com
}

Ilmu Hukum, Fakultas Hukum, Universitas Pattimura

\begin{abstract}
ABSTRAK
Narkotika Golongan I untuk kepentingan pelayanan kesehatan merupakan perbuatan yang dilarang dan memiliki konsekuensi yuridis apabila dilanggar yang tertuang didalam pasal 111 - 116 UU Narkotika, dan sanksi pidana minimum khusus didalam masing-masing pasal tersebut bervariasi yaitu 3-6 tahun. Pidana Minimum Khusus adalah sanksi pidana paling singkat yang dapat dijatuhkan oleh hakim terhadap terdakwa yang diatur oleh Undang-Undang khusus (Undang-Undang di luar KUHP).Dalam Putusan Pengadilan Nomor 111/ Pid.Sus/PN Sag, terjadi pertentangan antara keadilan dan kepastian hukum. Dari segi kepastian hukum, penerapan sanksi pidana yang dijatuhkan hakim tidak sesuai dengan pidana minimum khusus yang diatur didalam rumusan pasal 116 ayat (1). Dari segi keadilan, penggunaan Narkotika Golongan I dalam hal ini ganja pada perkara ini tidak dilakukan untuk keuntungan diri si terdakwa, maupun untuk di edarkan tetapi untuk pengobatan istrinya (kepentingan kemanusiaan). Sehingga hakim putusan hakim adalah putusan yang progresif dengan menerobos pidana minimum khusus yang tertera pada pasal 116 ayat (1).
\end{abstract}

Kata Kunci : Sanksi, Narkotika, Pidana 


\begin{abstract}
Narcotics Category I for health care are forbidden and have judicial consequences if violated which written in Article 111-116 Law on Narcotics, and with specialized minimum criminal punishment characterized by each article are varied from 3-6 years. The specialized minimum punishment is the shortest criminal punishment which can be imposed by judge towards an accused based on Specialised Law (Law outside Criminal Code). In the Court Verdict No. 111/Pid.Sus/PN Sag there's a contradiction between legal justice and legal certainty. From the legal certainty, the criminal sanction implementation that delivered by the judge were inconsistent with specialized minimum punishment in Article 116 paragraph (1). From the justice side, the use of Narcotics Category I, in this case: Marijuana are not for the interest of an accused one, nor to distribute but for his wife treatment (humanity interest). Therefore judge verdict is a progressive decision by a breakthrough specialized minimum punishment found in Article 116 paragraph (1).
\end{abstract}

Keywords: Punishment, Narcotics, Criminal

\section{A. Latar Belakang}

Pembangunan nasional

Indonesia bertujuan mewujudkan manusia Indonesia seutuhnya dan masyarakat Indonesia seluruhnya yang adil, makmur sejahtera dan damai berdasarkan Pancasila dan UndangUndang Dasar 1945. Untuk mewujudkan masyarakat Indonesia yang sejahtera tersebut perlu peningkatan secara terus-menerus usaha-usaha dibidang pengobatan dan pelayanan kesehatan termasuk ketersediaan narkotika sebagai obat, disamping pengembangan ilmu pengetahuan meliputi penelitian, pendidikan dan pengajaran sehingga ketersediaannya perlu dijamin melalui kegiatan produksi dan impor.

Pembangunan kesehatan sebagai bagian integral dari pembangunan nasional diarahkan guna tercapainya kesadaran, kemauan dan kemampuan hidup sehat bagi setiap penduduk agar dapat mewujudkan derajat kesehatan yang optimal, yang dilakukan melalui berbagai upaya kesehatan, diantaranya penyelenggaraan pelayanan kesehatan kepada masyarakat. ${ }^{1}$

\footnotetext{
${ }^{1}$ Mardani. Penyalahgunaan Narkoba: Dalam Perspektif Hukum Islam dan Hukum Pidana Nasional ,Jakarta: PT. Raja Grafindo, Tahun 2008, .1.
} 
Meskipun narkotika sangat diperlukan untuk pengobatan dan pelayanan kesehatan, bukan berarti bahwa semua golongan narkotika ini di legalkan peruntukannya untuk alasan medis. Sebagaimana diatur didalam Undang-Undang Nomor 35 tahun 2009 tentang Narkotika (selanjutnya disingkat UU Narkotika) khususnya pada pasal 6, dijelaskan bahwa narkotika dibedakan menjadi 3 golongan yaitu Golongan I, Golongan II dan Golongan III. Selanjutnya pasal 8 ayat (1) UU ini menjelaskan bahwasanya Narkotika Golongan I dilarang digunakan untuk kepentingan pelayanan kesehatan, kemudian pada pasal 8 ayat (2) mangatur bahwa:

Dalam jumlah terbatas, Narkotika Golongan I dapat digunakan untuk kepentingan pengembangan ilmu pengetahuan dan teknologi dan untuk reagensia diagnostik, serta reagensia laboratorium setelah mendapatkan persetujuan Menteri atas rekomendasi Kepala Badan Pengawas Obat dan Makanan.

Berdasarkan ketentuan diatas, maka bisa dikatakan bahwasanya penggunaan Narkotika Golongan I untuk kepentingan pelayanan kesehatan merupakan perbuatan yang dilarang dan memiliki konsekuensi yuridis apabila dilanggar yang tertuang didalam pasal 111 - 116 UU Narkotika, dan sanksi pidana minimum khusus didalam masingmasing pasal tersebut bervariasi yaitu 3-6 tahun. Pidana Minimum Khusus adalah sanksi pidana paling singkat yang dapat dijatuhkan oleh hakim terhadap terdakwa yang diatur oleh Undang-Undang khusus (UndangUndang di luar KUHP).

Didalam realitas penegakan hukum tindak pidana Narkotika ada satu kasus yang menarik untuk dianalisis yaitu pada perkara kepemilikan narkotika golongan I yakni ganja yang ditanam sendiri oleh Fidelis Arie Sudewarto yang dipergunakan untuk pengobatan penyakit syringomelia yan istrinya. Syringomyelia adalah tumbuhnya kista berisi cairan (syrinx) di dalam sumsum tulang belakang. ${ }^{2}$

\footnotetext{
https://www.alodokter.com/syringomyelia, diakses tanggal 8/5/2019. Pukul 16.15. WIT.
} 
Akibat perbuatannya tersebut, berdasarkan putusan pengadilan nomor 111/Pid.Sus/PN Sag tahun 2017, oleh hakim yang meriksa perkara ini menjatuhkan pidana selama 8 (delapan) bulan terhadap dirinya. Jika dicermati seperti yang telah penulis uraikan sebelumnya maka terlihat bahwasanya vonis hakim terhadap Fidelis Arie Sudewarto merupakan pidana penjara dibawah pidana minimum yang ditentukan UU Narkotika khusus untuk penyalahgunaan Narkotika Golongan I.

Berdasarkan uraian diatas maka yang menjadi permasalahan pada penulisan jurnal ini yaitu: Bagaimana Penerapan Sanksi Pidana Minimum Khusus Pada Tindak Pidana Narkotika dalam Putusan Nomor 111/Pid.Sus/2017/PN Sag ?

\section{B. Hasil dan Pembahasan}

Undang-Undang Narkotika menyebutkan bahwa narkotika adalah zat atau obat yang berasal dari tanaman atau bukan tanaman, baik sistetis maupun semi sintetis, yang dapat menyebabkan penurunan atau perubahan kesadaran, hilangnya rasa, mengurangi sampai menghilangkan rasa nyeri, dan dapat menimbulkan ketergantungan, yang dibedakan kedalam 3 (tiga) Golongan, yaitu: ${ }^{3}$

a. Narkotika Golongan I, adalah narkotika yang paling berbahaya. Daya adiktifnya sangat tinggi. Golongan ini tidak boleh digunakan untuk kepentingan apapun, kecuali untuk penelitian dan ilmu pengetahuan. Contohnya adalah tanaman ganja, opium mentah, opium masak seperti candu, jicing dan jicingko, tanaman koka, daun koka, kokain mentah, kokaina, tetrahydrocannabinol, delta 9 tetrahydrocannabinol dan lainnya (termasuk narkotika golongan I ini ada 65 (enam puluh lima) macamnya;

b. Narkotika Golongan II, adalah narkotika yang memiliki daya

\footnotetext{
${ }^{3}$ Badan Narkotika Nasional, 2014. Pencegahan Penyalahgunaan Narkoba Bagi Masyarakat, Jakarta. hal. 12-13.
} 
adiktif kuat, tetapi bermanfaat untuk pengobatan dan penelitian. Contohnya adalah alfasetilmetadol, alfametadol, Asetilmetadol, benzetidin, Betametadol, Betaprodina, Difenoksilat, Difenoksin, Dipipanona, Drotebanol, Etilmetiltiambutena,

Etokseridina, Etonitazena, Furetidina, Hidrokodona, Hidroksipetidina, Hidromorfinol dan lainnya (termasuk narkotika golongan II ini ada 86 (delapan puluh enam) macamnya;

c. Narkotika Golongan III, adalah narkotika yang memiliki daya adiktif ringan. Contohnya adalah Asetildihidrokodeina, Dekstropropoksifena, Etilmorfina, Kodeina, Nikodikodina, Nikokodina, Norkodeina, Polkodina, Propiram, Buprenorfina, dan lainnya (termasuk narkotika golongan III ini ada 13 (tiga Belas) macam termasuk beberapa campuran lainnya.

Berdasarkan cara pembuatannya, narkotika dibedakan juga kedalam 3 (tiga) golongan, yaitu :

1) Narkotika Jenis Alami

Ganja dan Koka menjadi contoh dari Narkotika yang bersifat alami dan langsung bisa digunakan melalui proses sederhana. Karena kandungannya yang masih kuat, zat tersebut tidak diperbolehkan untuk dijadikan obat. Bahaya narkoba ini sangat tinggi dan bisa menyebabkan dampak buruk bagi kesehatan jika disalahgunakan. Salah satu akibat fatalnya adalah kematian.

2) Narkotika Jenis Sintetis

Narkotika Sintetis adalah Narkotika yang dibuat dari bahan kimia dan digunakan untuk pembiusan atau 
pengobatan bagi mereka yang mengalami

ketergantungan narkoba. Narkotika sintesis berfungsi sebagai pengganti sementara untuk mencegah rehabilitasi sehingga penyalahgunaan dapat menghentikan ketergantungannya. Adapun contoh dari narkotika jenis sintetis antara lain: Amfetamin, Metadon, Deksamfetamin, dan sebagainya.

3) Narkotika Jenis Semi Sintetis Narkotika Semi Sintetis adalah berbagai jenis narkotika alami yang diolah dan diambil zat adiktifnya ( Intisarinya ) agar memiliki khasiat yang lebih kuat sehingga dapat dimanfaatkan untuk kepentingan kedokteran. Beberapa jenis Narkotika Semi Sintesis yang disalah gunakan adalah antara lain:
Morfin, Heroin, Kodein, dan lain-lain.

Penyalahgunaan Narkotika adalah pemakaian narkotika diluar indikasi medik, tanpa petunjuk atau resep dokter, dan pemakaiannya bersifat patologik (menimbulkan kelainanan) dan menimbulkan hambatan dalam aktivitas di rumah, sekolah atau kampus, tempat kerja dan lingkungan sosial. Ketergantungan narkotika adalah kondisi yang kebanyakan diakibatkan oleh panyalahgunaan zat yang disertai dengan adanya toleransi zat (dosis semakin tinggi) dan gejala putus zat. ${ }^{4}$

Permasalahan penyalahgunaan dan ketergantungan narkotika mempunyai dimensi yang luas dan kompleks, baik dari sudut medis, maupun psikososial (ekonomi, politik sosial, budaya, kriminalitas, kerusuhan masal dan lain sebagainya. Dampak yang sering kali terjadi atau dirasakan ditengah masyarakat dari penyalahgunaan/ketergantungan narkotika antara lain: 
a. Merusak hubungan kekeluargaan;

b. Menurunkan kemampuan belajar dan produktivitas kerja secara drastis;

c. Sulit membedakan mana perbuatan yang baik maupun buruk;

d. Perubahan perilaku menjadi anti sosial (perilaku maladaptif);

e. Gangguan kesehatan (fisik dan mental);

f. Mempertinggi jumlah kecelakaan lalu lintas;

g. Tindak kekerasan;

h. Dan tindak kriminalitas lainnya.

Dari dampakya, narkotika bisa dibagi menjadi 3 (tiga), yaitu: ${ }^{5}$

a) Depresan, yaitu menekan sistem syaraf pusat dan mengurangi aktifitas fungsional tubuh sehingga pemakai merasa tenang, bahkan bisa membuat pemakai tidur dan tak sadarkan diri. bila kelebihan dosis bisa mengakibatkan kematian. Jenis narkotika depresan antara lain opioda, dan berbagai turunannya seperti morphin dan heroin. Contoh yang popular sekarang adalah putaw.

b) Stimulan, yaitu merangsang fungsi tubuh dan meningkatkan kegairahan serta kesadaran. Jenis timulan: Kafein, Kokain, Amphetamin. Contoh yang sekaran sering dipakai adalah sabhu dan ekstasi.

c) Halusinogen, dampak utamanya adalah mengubah daya persepsi atau

\footnotetext{
${ }^{5}$ BNN...,Op.Cit. hal 18.
} 


$$
\begin{aligned}
& \text { mengakibatkan } \\
& \text { halusinasi. Halusinogen } \\
& \text { kebanyakan berasal dari } \\
& \text { tanaman seperti } \\
& \text { mescaline dari kaktus } \\
& \text { dan psilocybin dari } \\
& \text { jamur-jamuran. Selain } \\
& \text { itu ada juga yang } \\
& \text { diramu di laboratorium } \\
& \text { seperti LSD. Yang } \\
& \text { paling banyak dipakai } \\
& \text { adalah marijuana atau } \\
& \text { ganja. }
\end{aligned}
$$

Bentuk-bentuk penyalahgunaan Narkotika khususnya Narkotika golongan I menurut UU Narkotika, yaitu setiap orang yang tanpa hak dan melawan hukum:

1. Menanam, memelihara, memiliki, menyimpan, menguasai atau menyediakan narkotika Golongan (satu) dalam bentuk tanaman diatur dalam pasal 111 ayat (1) dan (2) diancam dengan pidana paling singkat 5 tahun dan paling lama seumur hidup, denda paling sedikit 800 juta dan paling banyak 8 miliar;

2. Memiliki, menyimpan, menguasai,atau menyediakan narkotika bukan tanaman; narkotika golongan I ketentuan pidananya yaitu pasal 112 ayat (1), golongan 2 , pasal 117 ayat (1), dan narkotika golongan 3 diatur dalam pasal 122 ayat (1), dengan pidana kurungan paling singkat 2 sampai 4 tahun dan denda paling sedikit 400 juta sampai 800 juta, sedangkan paling banyak pidana kurungan 7 sampai 12 tahun dan dengan denda maksimal 3 sampai 8 miliar;

3. Memiliki, menyimpan, menguasai,atau menyediakan narkotika bukan tanaman lebih dari 5 gram, narkotika golongan I (pasal 112 ayat (2)), golongan 2 (pasal 117 ayat (2)), golongan 3 (pasal 122 
ayat (2)), diancam dengan pidana kurungan paling singkat 5 tahun dan paling lama 20 tahun dengan denda maksimal 8 miliar;

4. Memproduksi, mengimpor, mengekspor atau menyalurkan, narkotika golongan I (pasal 113 ayat (1)), golongan 2 (pasal 118 (1)), golongan 3 (pasal 123 ayat (1)), diancam dengan pidana kurunga paling singkat 5 tahun dan paling lama 15 tahun dan denda paling sedikit 1 miliar dan paling banyak 10 miliar;

5. Memproduksi, mengimpor, mengekspor atau menyalurkan bentuk tanaman: lebih dari $1 \mathrm{KG} / 5$ BTG, bukan tanaman: lebih 5 Gram, narkotika golongan I (pasal 113 ayat (2)), golongan 2 (pasal 118 ayat (2)), golongan 3 (pasal 123 ayat (2)), dipidana dengan pidan kurungan paling singkat 5 tahun dan paling lama 20 tahun, dengan denda maksimum 10 miliar;

6. Menawarkan untuk dijual, menjual, membeli, menerima, menjadi perantara dalam jual beli atau menyerahkan, narkotika golongan I (pasal 114 ayat (1)), narkotika golongan II (pasal 119 ayat (1)), narkotika golongan III (pasal 124 ayat (1)), diancam dengan pidana kurungan paling singkat 3 sampai 5 tahun dan paling lama 10 sampai 20 tahun dengan denda paling sedikit 600 juta sampai I miliar sedangkan paling banyak 5 sampai 10 miliar;

7. Menawarkan untuk dijual, menjual, membeli, menerima, menjadi perantara dalam jual beli atau menyerahkan bentuk tanaman: lebih $1 \mathrm{KG} / 5$ BTG, bukan tanaman: lebih 
5 Gram, narkotika golongan

I (pasal 114 ayat (2)), narkotika golongan II (pasal 119 ayat (2)), narkotika golongan III (pasal 124 ayat (2)), diancam dengan pidana kurungan paling singkat 5 tahun dan paling lama 20 tahun dengan denda maksimal 10 miliar;

8. Membawa, mengirim, mengangkut atau mentransito, narkotika golongan I (pasal 115 ayat(1)), narkotika golongan II (pasal 120 ayat (1)), narkotika golongan III (pasal 125 ayat(1)), dipidana dengan pidana kurungan paling singkat 2 sampai 4 tahun dan paling lama 7 sampai 12 tahun, dengan denda paling sedikit 400 juta sampai 800 juta dan paling banyak 3 miliar sampai 8 miliar;

9. Membawa, mengirim, mengangkut atau mentransito bentuk tanaman: lebih dari $1 \mathrm{KG} / 5$ BTG, bukan tanaman lebih dari 5 Gram, narkotika golongan I (pasal 115 ayat(2)), narkotika golongan II (pasal 120 ayat (2)), narkotika golongan III (pasal 125 ayat(2)), dipidana dengan pidana kurungan paling singkat 3 sampai 5 tahun dan paling lama 10 sampai 20 tahun, dengan denda maksimal 8 miliar;

10. Menggunakan narkotika terhadap atau diberikan untuk orang lain, narkotika golongan I (pasal 116 ayat (1)), narkotika golongan II (pasal 121 ayat (1)), narkotika golongan 3 (pasal 126 ayat (1)), dipidana dengan penjara kurungan paling singkat 3 sampai 5 tahun dan paling lama 10 sampai 15 tahun dan denda paling sedikit 600 juta sampai 1 miliar 
dan paling banyak 5 miliar sampai 10 miliar;

11. Menggunakan narkotika terhadap atau diberikan untuk orang lain mengakibatkan orang lain mati atau cacat permanen, narkotika golongan I (pasal 116 ayat (2)), narkotika golongan II (pasal 121 ayat (2)), narkotika golongan 3 (pasal 126 ayat (2)), dipidana dengan penjara kurungan paling singkat 5 tahun dan paling lama 20 tahun dan denda maksimal 10 miliar.

Berdasarkan putusan Nomor 111/Pid.Sus/PN. Sag, terlihat bahwa jaksa penuntut umum menggunakan surat dakwaan alternatif untuk mendakwa perbuatan terdakwa. Adapun bentuk dakwaan ini digunakan untuk memberi pilihan kepada hakim dalam menerapkan salah satu dari dakwaan-dakwaan yang diajukan di pengadilan. ${ }^{6}$ Ciri dari dakwaan ini, yaitu antara dakwaan satu dengan dakwaan yang lain menggunakan kata penghubung "atau”. Dan adapun pasalpasal yang didakwakan yaitu Pasal 111 Ayat (2) Pasal 113 Ayat (2) serta Pasal 116 Ayat (1) UU Nakotika.

Fakta yang terungkap di persidangan yaitu terdakwa menanam ganja kurang lebih pada bulan mei Tahun 2016 karena isteri terdakwa menderita sakit semenjak oktober Tahun 2013 dan sedang hamil kurang lebih 5 bulan. Oleh terdakwa, istrinya dibawa ke rumah sakit Sanggau dan ditangani oleh Dokter kandungan, hasil pemeriksaan Dokter menyatakan ini hanya bawaan hamil karena tidak berani menyimpulkan penyakit diderita oleh istri terdakwa. Kemudian terdakwa mengobati isterinya kepada Mak Ngah yang mempunyai kemampuan membantu orang yang melahirkan lalu isteri terdakwa diurut sampai bisa beraktifitas lagi walaupun

${ }^{6}$ M.Yahya Harahap, 2000. Pembahasan Permasalahan dan Penerapan KUHAP. Jakarta: Sinar Grafika. 400. 
tidak begitu terlalu baik dan sampai akhirnya normal kembali.

Kemudian pada umur anak terdakwa yang kedua kurang lebih 5 bulan istri terdakwa kembali mengalami sakit yang dirasahkan tubuhnya sebelah kanan sering berkeringat dan kesemutan sampai akhirnya tidak bisa buang air seni. Terdakwa kembali membawa istrinya ke rumah sakit Sanggau dan dari hasil pemeriksaan, dokter juga tidak berani memastikan dengan akurat terkait penyakit yang diderita isterinya. Pada tahun 2014 kondisi isteri terdakwa kembali tidak bisa buang air seni, sehingga terdakwa merujuknya ke pontianak dan di rumah sakit tersebut istri terdakwa mulai diperiksa namun Dokter yang menanganinya tersebut juga tidak berani memastikan apa sebenarnya penyakit yang diderita isteri terdakwa tersebut akan tetapi dokter menduga bahwa isteri terdakwa menderita penyakit Syringomyelia.

Waktu itu kondisi separuh tubuhnya tidak bisa digerakan sehingga terdakwa mempunyai keinginan untuk berobat istrinya ke pulau jawa karena isteri terdakwa tersebut sering juga mengalami sesak napas. Dokter memberitahukan kepada terdakwa kalau di rujuk, dikhawatirkan bisa membahayakan kondisi kesehatannya yang berakibatkan tidak tersedianya fasilitas kesehatan. Sebelum pulang ke Sanggau terdakwa ke Bodok guna membawa isteri terdakwa berobat alternatif dan disana berobat kurang lebih dua minggu dan terdakwa lihat kondisi isteri terdakwa mulai membaik dan sudah bisa menggerakan kakinya namun yang mengobati isteri terdakwa menyampaikan kepada terdakwa belum tau apa penyebabnya.

Kurang lebih satu bulan orang yang mengobati isteri terdakwa tersebut meninggal sehingga pengobatan alternatif yang dilakukan selama ini dihentikan. selanjutnya terdakwa menemui nenek Anjeli yang biasa mengobati orang, akan tetapi tidak ada perubahan akhirnya terdakwa kembali lagi melanjutkan pengobatan istrinya ke tempat panti pijat atau 
refleksi namun kondisi isteri terdakwa juga tidak membaik. Pada bulan desember 2015 isteri terdakwa kembali tidak bisa buang air seni lagi, akibatnya terdakwa bawa ke rumah sakit umum Sanggau dan juga tidak ditemukan apa penyakitnya dan nafsu makannya berkurang dan kadangkadang muntah, melihat kondisi tersebut Dokter menyarankan untuk memeriksa kondisi piskiologis dan dirujuk ke Singkawang namun karena disana tidak ada ruang untuk rawat inap jadi isteri terdakwa dialihkan ke rumah sakit lain yang ada dikota Singkawang kemudian isteri terdakwa diperiksa namun Dokter tersebut juga tidak menemukan masalah kejiwaan isteri terdakwa tersebut.

Terdakwa disarankan untuk mengembalikan kondisi kejiwaannya dirumah saja, kemudian terdakwa bawa lagi isteri terdakwa pulang ke Sanggau namun baru satu hari kembali lagi isteri terdakwa tidak dapat buang air seni kemudian terdakwa bawa lagi ke rumah sakit umum Sanggau dan setelah dirawat beberapa hari, kotektor yang dipasang terjadi pendarahan, lalu dokter bilang ada dugaan isteri terdakwa terkena Syringomyelia. Pada saat yang bersamaan setelah dilakukan pemeriksaan lebih dalam dari situ barulah Dokter menyatakan bahwa isteri terdakwa tersebut terkena penyakit Syringomyelia, dan saat yang bersamaanterakwa melihat luka kecil di punggung istrinya.

Kondisi fisiknya sudah menurun dan solusi penyakit tersebut sebenarnya harus dioperasi akan tetapi kondisi isteri terdakwa tidak memungkinkan untuk dioperasi karena terlalu beresiko sementara dari rumah sakit sendiri sudah tidak ada lagi penanganan medis jadi terdakwa disarankan untuk mengistirahatkan isteri di rumah, dan semenjak saat itulah terdakwa lalu mencari tahu dan informasi tentang penyakit tersebut, sementara luka yang dipunggung isteri terdakwa semakin membesar.

Pertama kali terdakwa mendapat informasi Syringomyelia itu dari internet dan terdakwa kenal dengan seseorang bernama Bet Muyen dia 
Warga Negara Amerika yang menderita Sringomyelia. Terdakwa mancari lagi informasi dan menemukan satu halaman yang ditulis Asna Evan dari Kanada dia juga penderita Syringomyelia dan sudah tiga tahun menggunakan pengobatan secara medis namun tidak berhasil kemudian ternyata diketahui ia menggunakan ganja dan dia bisa bertahan dan merasa lebih baik.

Kemudian terdakwa mencari tahu lagi dan menemukan artikel salah satu hasil penelitian dari seorang Dokter yang berasal dari Israel dia sendiri adalah orang pertama yang berhasil mengisolasikan salah satu kandungan dari ganja dan dikatakan bahwa kandungan yang ada pada ganja tersebut mampu untuk mengobati beberapa penyakit kanker, efilepsi dan lain-lain. Kemudian terdakwa mencari lagi ternyata banyak penelitian tentang ganja tersebut dan terdakwa merasa yakin bahwa ganja tersebut bisa digunakan untuk obat.

Terdakwa mendapatkan ganja, bermula pada saat terdakwa di terminal untuk membeli gado-gado untuk isteri terdakwa dan bertemu orang yang tak dikenal dan menceritakan kondisi kesehatan istrinya yang sangat membutuhkan ganja untuk pengobatan. Orang tersebut bersedia membantu terdakwa mencarikan bibit ganja tersebut dan mengatakan harga 1 ons ganja tersebut Rp.900.000, Selang 3 hari orang tersebut menghubungi terdakwa lewat HP dan terdakwa disuruh datang ke terminal Bis Sanggau untuk mengambil paket, dan setelah terdakwa datang lalu dikasih kotak kecil dan dikotak tersebut ada nomor HP terdakwa kemudian paket tersebut terdakwa ambil dan bawa pulang ke rumah, setelah dibuka ternyata di dalamnya terdapat ganja kering lengkap dengan, daun, batang dan bunganya.

Terdakwa langsung membuat ekstrak ganja tersebut dan diberikan kepada isteri terdakwa dan hal pertama yang terdakwa lihat isteri terdakwa langsung mau minta makan kurang lebih 30 menit setelah terdakwa 
memberikan ekstrak ganja tersebut walaupun tidak banyak akan tetapi lebih banyak makan dari biasanya. Terdakwa terpikir dengan biji ganja tersebut, dari buku yang terdakwa baca dari seorang ahli akupuntur dari Amerika Serikat yang mengatakan kalau ganja itu untuk pengobatan tidak seperti ganja pada umumnya dan ganja tersebut ditanam secara khusus untuk mendapatkan kandungan untuk pengobatan dan ganja tersebut ditanam secara organik tidak mempergunakan pupuk.

Beberapa biji yang terdakwa tanam tidak semuanya tumbuh ada sekitar empat pohon yang tumbuh dan dari empat pohon yang tumbuh tersebut terdakwa pergunakan untuk bibit lagi sampailah menjadi 39 (tiga puluh sembilan) batang tersebut. Untuk dipakai sebagai pengolahan obat terdakwa pakai bunganya sebagai obat intinya namun ada juga daunnya terdakwa gunakan untuk dicampurkan dalam makanan sedangkan bunganya terdakwa olah menjadi ekstrak atau minyak. terdakwa mengetahui tentang pengolahan ganja tersebut dari bukubuku yang pernah terdakwa baca dan buku-buku tersebut adalah buku-buku tentang marijuana.

Pada perkara ini tuntutan jaksa, pada pokoknya meminta hakim yang memeriksa dan mengadili perkara ini untuk memidanakan terdakwa selama 5 (lima) bulan penjara. Dimana surat tuntutan telah selaras dengan surat dakwaan karena surat tuntutan merupakan representasi sikap dari Penuntut Umum terhadap bukti-bukti yang terungkap pada fakta persidangan dan telah sesuai dengan surat dakwaan. Namun menarik disini jika dilihat dari pasal-pasal yang termuat didalam surat dakwaan alternatif yang mana jaksa penuntut umum menggunakan pasal 111 Ayat (2) Pasal 113 Ayat (2) serta Pasal 116 Ayat (1) UU Nakotika pidana minimum khusus yang tertera dalam masing-masing pasal dimaksud adalah 5-6 tahun.

Seperti diketahui UU Narkotika mengakomodir tindak pidana diluar KUHP dan berbeda dengan KUHP, selain mengatur segi-segi hukum 
materiil diantaranya perumusan tindak pidana, jenis hukuman, dan sebagainya. UU ini juga memuat secara khusus tentang hukum formilnya mulai dari cara melakukan hukum pidana materiil, seperti penyidikan, penuntutan, mengadili perkara, dan sebagainya. Kekhususan dalam segi hukum materilnya diantaranya adalah penerapan ancaman pidana penjara minimum ${ }^{7}$. Dengan demikian maka lamanya pidana yang diminta jaksa penuntut umum kepada hakim adalah tidak sesuai dengan amanah UU Narkotika.

Hakim dalam memeriksa dan memutus perkara harus didasarkan pada surat dakwaan jaksa penuntut umum, sebagaimana diatur didalam pasal 182 ayat (3) dan ayat (4) Kitab Undang-ndang ukum Acara Pidana. Selanjutnya didalam merumuskan suatu putusan sepatutnya hakim harus mengkaitkannya dengan tujuan pemidanaan yang terdiri dari kepastian, keadilan, dan kemanfaatan

\footnotetext{
${ }^{7}$ Hari Sasangka, 2003. Narkotika dan Psikotropika Dalam Hukum Pidana, Bandung : PT. Mandar Maju, hal. 127-128.
}

hukum, dan ketiganya harus diperhatikan kedudukannya secara proporsional. Namun apabila terjadi pertentangan antara kepastian dan keadilan. Maka yang akan dikedepankan adalah keadilan.

Untuk penerapan pidana minimum khusus pada tindak pidana narkotika yang tertuang dalam putusan hakim dalam perkara ini, Dari segi kepastian hukum, penerapan sanksi pidana yang dijatuhkan hakim tidak sesuai dengan pidana minimum khusus yang diatur didalam rumusan pasal 116 ayat (1) yang secara eksplisit mengatur 5 (lima) tahun adalah sanksi pidana yang paling rendah yang dapat diterapkan terhadap seorang terdakwa yang terbukti secara sah dan meyakinkan melanggar ketentuan dalam pasal ini sedangkan oleh hakim terdakwa dijatuhi pidana 8 (delapan) bulan.

Dari segi keadilan, penggunaan Narkotika Golongan I dalam hal ini ganja pada perkara ini tidak dilakukan untuk keuntungan diri si terdakwa, maupun untuk di edarkan tetapi untuk 
pengobatan istrinya (untuk kepentingan kemanusiaan). Sehingga vonis 8 (delapan) bulan terhadap terdakwa sudah tepat, karena menurut hemat penulis, putusan yang dikeluarkan oleh hakim merupakan putusan yang progresif karena tidak kaku dengan rumusan UU Narkotika dan hal ini juga sejalan dengan pendapat Satjipto Rahardjo, yang mengatakan bahwa keadilan itu tidak hanya terbatas seperti yang dirumusan pasal-pasal didalam undang-undang, namun lebih banyak digali di dalam denyut-denyut kehidupan masyarakat. ${ }^{8}$

Hal ini juga berkaitan erat dengan Pasal 5 ayat (1) UndangUndang Nomor 48 Tahun 2009 Tentang Kekuasaan Kehakiman (selanjutnya disingkat UU Kehakiman), yang mana secara substantif menjelaskan bahwa: "Hakim dan hakim konstitusi wajib menggali, mengikuti, dan memahami nilai-nilai hukum dan rasa keadilan yang hidup dalam masyarakat.

${ }^{8}$ Mahrus Ali, 2013, Membumikan Hukum Progresif, Jogyakarta: Aswaja Pressindo, hal.2.
Mengenai keadilan juga telah tertuang di dalam pasal 3 Ayat (1) UndangUndang No. 48 Tahun 2009 tentang Kekuasaan Kehakiman yang merupakan salah satu asas penyelenggaraan kekuasaan peradilan yang berbunyi peradilan dilakukan "DEMI KEADILAN BERDASARKAN KETUHANAN YANG MAHA ESA"

Dengan demikian menurut hemat penulis baik tuntutan jaksa penuntut umum maupun pidana penjara yang dijatuhkan hakim yang notabenenya dibawah sanksi pidana minimum khusus didalam UU Narkotika untuk diterapkan terhadap Fidelis Arie Suwarto adalah suatu langkah yang progresif dalam melakukan penegakan hukum terhadap tindak pidana narkotika.

Sebenarnya upaya untuk menerobos pidana minimal khusus didalam UU Narkotika sudah diatur didalam 2 (dua) Surat Edaran Mahkamah Agung (selanjutnya disingkat SEMA) yaitu SEMA Nomor 7 Tahun 2012 dan SEMA Nomor 3 
tahun 2015 tentang Pemberlakuan Rumusan Hasil Rapat Pleno Kamar Mahkamah Agung Tahun 2015 sebagai pedoman Pelaksanaan Tugas Bagi Pengadilan. Namun substansi SEMA ini mengatur hal yang berbeda dengan pokok perkara Fidelis Arie Suwarto. Dimana intinya SEMA ini menjelaskan jaksa mendakwa dengan pasal 111 atau pasal 112 UU Narkotika, namun berdasarkan fakta hukum yang terungkap di persidangan terbukti pasal 127 UU Narkotika yang mana pasal ini tidak didakwakan, terdakwa terbukti sebagai pemakai dan jumlahnya relatif kecil (SEMA Nomor 4 Tahun 2010), maka hakim memutus sesuai dengan surat dakwaan tetapi dapat menyimpangi ketentuan pidana minimum khusus dengan membuat pertimbangan yang cukup.

\section{Penutup}

\begin{tabular}{lcr}
\multicolumn{1}{c}{ Perumusan } & suatu & putusan \\
sepatutnya hakim & harus \\
mengkaitkannya dengan & tujuan \\
pemidanaan yang terdiri & dari \\
kepastian, keadilan, dan kemanfaatan
\end{tabular}

hukum, dan ketiganya harus diperhatikan kedudukannya secara proporsional. Namun dalam Putusan Pengadilan Nomor 111/ Pid.Sus/PN Sag, terjadi pertentangan antara keadilan dan kepastian hukum. Dari segi kepastian hukum, penerapan sanksi pidana yang dijatuhkan hakim tidak sesuai dengan pidana minimum khusus yang diatur didalam rumusan pasal 116 ayat (1). Dari segi keadilan, penggunaan Narkotika Golongan I dalam hal ini ganja pada perkara ini tidak dilakukan untuk keuntungan diri si terdakwa, maupun untuk di edarkan tetapi untuk pengobatan istrinya (kepentingan kemanusiaan). Sehingga hakim putusan hakim adalah putusan yang progresif dengan menerobos pidana minimum khusus yang tertera pada pasal 116 ayat (1).

Untuk itu sebaiknya pemerintah melalui institusi yang berwenang dapat melakukan penelitian lagi apakah dimungkinkan secara ilmu pengetahuan ganja dapat digunakan untuk kepentingan kesehatan. Sehingga hal ini bisa disesuaikan 
perumusannya secara ketat didalam sperti ini tidak terjadi lagi.

UU Narkotika. Sehingga kasus-kasus

\section{Daftar Pustaka}

Ali, M. (2013). Membumikan Hukum Progresif. Yogyakarta: Aswaja Pressindo.

Harahap, M. Y. (2012). Pembahasan Permasalahan dan Penerapan KUHAP. Jakarta: Sinar Grafika.

Mardani. (2008). Penyalahgunaan Narkoba : Dalam Perspektif Hukum Islam dan Hukum Pidana . Jakarta: PT Raja Grafindo.

Nasional, B. N. (2017). Pencegahan Penyalagunaan Narkoba Bagi Masyarakat. Jakarta: Badan Narkotika Nasional.

Sasangka, H. (2003). Narkotika dan Psikotropika Dalam Hukum Pidana. Bandung: PT. Mandar Maju. 